Ks. Edward Sienkiewicz ${ }^{1}$

\title{
Chrystocentryczny wymiar postu i umartwienia w pismach św. Hieronima ze Strydonu
}

Święty Hieronim był jednym z najbardziej surowych ascetów swojego czasu i w ogóle w historii chrześcijaństwa ${ }^{2}$. Nie zawsze się o tym pamięta. Podobnie jak o jego ważnych rozstrzygnięciach teologicznych, zwłaszcza chrystologicznych ${ }^{3}$, klasyfikując go najczęściej jako egzegetę i tłumacza Pisma Świętego. Tymczasem choćby pobieżna znajomość życiorysu tej niezwykłej postaci pozwala dostrzec, że wiele jej ocen i określeń, powstałych na potrzeby usystematyzowania dorobku Strydończyka, ukazania znaczenia jego życia oraz dzieła w tradycji chrześcijańskiej, zawiera dość daleko idące uogólnienia lub jednostronności nie zawsze uwzględniające złożoność problemu wynikającą z osobistych decyzji autora Wulgaty, ale i szeroko rozumianego kontekstu ${ }^{4}$. Na tę złożoność składają się cechy jego charakteru ${ }^{5}$ i wyzwania właściwe jego epoce, do których należy zaliczyć - niejednokrotnie burzliwie dyskutowane i wywołujące spory - kwestie teologiczne.

1 Ks. prof. dr hab. Edward Sienkiewicz, profesor zwyczajny zatrudniony w Instytucie Teologicznym Uniwersytetu Szczecińskiego, kierownik Katedry Teologii Systematycznej, e-mail: esienkiewicz@op.pl; ORCID: 0000-0002-6711-9933.

2 B. Degórski, Wstęp, w: Hieronim, Żywoty mnichów Pawła, Hilariona, Malchusa, tł. B. Degórski, Kraków 1995, s. 11.

3 M.C. Paczkowski, Chrystologia Hieronima na tle teologii palestyńskiej przełomu IV $i$ Vwieku, VoxP 48 (2005) s. 159-186.

4 T. Jelonek, Hieronim, Kraków 2003, s. 79-80.

5 Charakteryzował się dość gwałtownym i wybuchowym temperamentem. Z wielkim trudem przychodziło mu zachować łagodność i wyrozumiałość, zwłaszcza wobec swoich przeciwników, o której tak wiele pisał w swoich ascetycznych tekstach, nie tylko zachęcając innych do tego, ale również wymagając. Potrafił być złośliwy, niewybredny w słowach, czasami zarozumiały, wrażliwy na pochwały pod swoim adresem, podobnie jak na nagany. 
Poza tym bardzo charakterystyczny styl pobożności po przełomie konstantyńskim, kiedy to poszukiwano najlepszych wzorców i sposobów chrześcijańskiej egzystencji po ustaniu prześladowań. Nowa sytuacja Kościoła w epoce postkonstantyńskiej bowiem niosła ze sobą nowe pokusy, wśród których chęć wygodnego urządzenia się w doczesności pod coraz bardziej bezpiecznym ,,parasolem” chrześcijaństwa ${ }^{6}$, zwykle niesłużąca najlepiej ostatecznemu dobru człowieka, okazała się dość poważna ${ }^{7}$. Dlatego w pobożności i duchowości, charakterystycznych dla tego okresu, zaczęto poszukiwać najlepszych sposobów realizowania ideałów chrześcijańskich i naśladowania Chrystusa. W tym właśnie czasie chrześcijaństwo znajduje w ascezie nowy wyraz radykalizmu, poszukując niejako swojej tożsamości, a pogaństwo, coraz wyraźniej ustępujące, walczy o przetrwanie ${ }^{8}$.

Stąd wielu chrześcijan, bardzo poważnie traktujących swoją decyzję pójścia za Chrystusem, wybierało pustelniczy i mniszy styl życia. Nie ograniczał się on tylko do odejścia od zgiełku charakterystycznego dla wielkich metropolii oraz poszukiwania służącej - przynajmniej niektórym - samotności. Poza pobożnościowym, kulturowym i teologicznym aspektem styl ten niósł ze sobą także wymiar ascetyczny. Nie był również celem sam w sobie, ponieważ miał służyć czemuś bardzo istotnemu w chrześcijaństwie, co spodziewano się osiągnąć w taki właśnie sposób. Co było tym celem i jak go sobie wówczas wyobrażano oraz realizowano, bardzo dobrze pokazuje życie i dzieło św. Hieronima. Jak wynika jednoznacznie z jednego i drugiego, Strydończyk rozumiał i traktował rozwijające się $\mathrm{W}$ nim powołanie chrześcijańskie poważnie i radykalnie, czemu daje wyraz między innymi w swoim liście pocieszającym do Juliana ${ }^{9}$, najprawdopodobniej jego rodaka z Dalmacji, kiedy pisze,

6 R. Stark, The Rise of Christianity. A Sociologist Reconsiders History, Princeton 1996; J.M. Lieu, Christian Identity in the Jewish and Graeco-Roman World, Oxford 2004; J.B. Rives, The Decree of Decius and the Religion of Empire, ,Journal of Roman Studies" 89 (1999) s. 135-154; H. Bourgeois - B. Sesboüé - P. Tihon, Znaki zbawienia, t. 3, tł. P. Rak, w: Historia dogmatów, red. B. Sesboüé, Kraków 2001, s. 333; M. Goodman, Rzym i Jerozolima. Zderzenie antycznych cywilizacji, tł. O. Zienkiewicz, Warszawa 2007, s. 398; P. de Labriolle, La réaction païenne. étude sur la polémique antichrétienne du ler au VI siècle, Paris 1984, s. 335-337; C.S. Bartnik, Fenomen Europy, Radom 2001, s. 79.

7 Hieronymus, Ep. 60, 11, tł. J. Czuj, Kraków 2010, s. 88*.

8 D. Hunter, Marriage, Celibacy and Heresy in Ancient Christianity: The Jovinianist Controversy, Oxford 2007, s. 51.

9 Julian, zamożny i hojny, wspierający materialnie Kościół, obywatel, który w bardzo krótkim czasie (w ciągu dwudziestu dni) stracił dwie córki, a następnie żonę. 
że ,przystępując do służby Bożej, przygotuj duszę swą na próbę"10. Tę próbę, czy raczej egzamin, autor Wulgaty zdawał przez całe swoje życie pośród licznych przeszkód oraz zadań, pokonywanych i realizowanych w sposób zapewniający mu zarówno funkcję wielkiego przykładu, jak i nauczyciela. Przy czym pochylając się nad tą postacią w ascetycznym wymiarze, należy pamiętać o podstawowym u Hieronima kluczu interpretacyjnym i zarazem swoistym wyznaczniku jego życia oraz pism. Chodzi tu o chrystocentryzm, zgodnie z którym o Chrystusie według Strydończyka najwięcej mówi Stary i Nowy Testament. W jednym i drugim jest On obecny, choć inaczej. Przesądza to w zasadzie o umiłowaniu przez niego Biblii ze względu na pierwotną oraz odmieniającą jego życie miłość do Jezusa Chrystusa i z tego samego powodu praktykowaniu surowej ascezy, aby w ten sposób nie tylko Jezusa jak najlepiej naśladować, ale również z Nim się jednoczyć.

\section{Na drodze do zjednoczenia z Jezusem Chrystusem w miłości}

Uważna lektura pism Strydończyka pozwala dostrzec dość interesujący fenomen. Otóż formułowane w nich tezy, pouczenia, przestrogi i niejednokrotnie bardzo surowa krytyka noszą na sobie ślad przeżyć i doświadczeń samego autora. Warto o tym pamiętać, analizując wspomnianą decyzję Hieronima dotyczącą chrześcijańskiej egzystencji, która w swoich skutkach okazała się wyjątkowo doniosła i radykalna, początkowo jednak, także dla niektórych jego przyjaciół, dość zaskakująca. Przybywający do Rzymu z prowincji młody człowiek pochodzenia rzymskiego nie różnił się jakoś specjalnie od podobnych sobie rówieśników starających się znaleźć swoje miejsce w wielkim świecie. Dobrą i sprawdzoną drogą do tego było pobieranie nauk od znanych w wiecznym mieście mistrzów. Od pewnej średniej - przynajmniej w jakimś znaczącym stopniu - nie odbiegało również jego poddawanie się urokom i przyjemnościom związanym z życiem najpierw w Rzymie, a później w Trewirze, do którego przeniósł się, by kontynuować studia i rozwijać swoje zainteresowania ${ }^{11}$.

Okazało się jednak, że Hieronim potrafił szybko docenić i wyjątkowo skutecznie korzystać z kulturowych oraz intelektualnych zdobyczy rzymskiej cywilizacji. Szczególnie Trewir na tym etapie życia Strydończyka wydaje się bardzo istotny. Ambitny i łaknący wiedzy odbywa on szereg bardzo pouczających podróży. Poznaje różnych ludzi, styka się z innymi

\footnotetext{
10 Hieronymus, Ep. 118, 4, s. 31*.

11 Jelonek, Hieronim, s. 66-67.
} 
kulturami i wierzeniami, ulegając nieukrywanej fascynacji. Nie pochłania go jednak ona bez reszty i nie przysłania całkowicie świata. Oprócz pogańskich, klasycznych autorów i budzących podziw dzieł sztuki do młodego człowieka, przejawiającego nieprzeciętne zdolności w gromadzeniu encyklopedycznej wiedzy oraz wykazującemu się już na tym etapie rzadko spotykaną erudycją, zdają się mocno przemawiać także chrześcijańscy męczennicy, których szczątki spoczywają w rzymskich ścianach ${ }^{12}$. Poza tym od wstąpienia do katechumenatu (drugi stopień) Hieronim nie rozstaje się praktycznie z Pismem Świętym, znajdując każdego dnia czas na lekturę i rozważanie przykuwających jego uwagę fragmentów. Wreszcie w liście do Rufina, pisanym z Trewiru, informuje, że postanawia zostać mnichem, co wywołuje pewne zdziwienie, choć takie fakty z życia nawet dość znaczących w antycznym świecie postaci od czasu do czasu miały miejsce. Do realizacji tych planów dochodzi w Rzymie, gdzie przyobleka mniszą szatę. Zanim wyjedzie na pustynię Chalkis, na wschodnim pograniczu Syrii, daje mocny impuls ascetyzmowi wiecznego miasta ${ }^{13}$. Podczas pobytu w stolicy imperium dość ostro krytykuje rzymskie duchowieństwo za życie niezgodne $\mathrm{z}$ jego stanem ${ }^{14}$, przez co przysparza sobie wielu nieprzyjació $1^{15}$. Niemalże pięcioletni pobyt na pustyni, po opuszczeniu na pewien czas Rzymu, związany jest z prawdziwym przełomem w życiu Strydończyka i pierwszymi - na taką skalę - doświadczeniami ascetycznymi obfitującymi w liczne, bardzo surowe wyrzeczenia oraz praktyki pokutne ${ }^{16}$.

O wspomnianej decyzji ascetycznego i naznaczonego surowym postem życia autora Wulgaty w perspektywie Chalkidy - stanowiącej proces szczególnego oczyszczenia - można powiedzieć, że była ona bardzo świadoma i gruntownie przemyślana ${ }^{17}$. I nie zmienią jej ani nie naruszą

12 Y. Chauffin, Święty Hieronim, tł. B. Durbajło, Warszawa 1977, s. 14-25.

13 M.G. Mara, Paulo di Tarso e il suo Epistolario. Ricerche storico-esegetiche, L'Aquila 1983, s. 60-61.

14 W liście 52 do prezbitera Nepocjana pisze, jakim powinien być duchowny (clericus): nie szukać korzyści światowych i nie mieć więcej, niż kiedy zaczynał pełnić swoją posługę, stając się duchownym. Powinien poza tym unikać niczym zarazy takich „duchownych", którzy wykorzystują swoje posługiwanie do robienia różnego rodzaju osobistych interesów i reklamy dla siebie. Obowiązkiem za to duchownego jest dzielenie się pokarmem z ubogimi i podróżnymi. Duchowny nie powinien przyjmować niewiast w mieszkaniu i mieszkać z nimi pod jednym dachem. Nie powinien przyjmować podarunków i unikać wyrzeczeń, choć poszcząc, powinien unikać zabobonów i przesady. Hieronymus, Ep. 52, 5-6, 12, s. 15*-18*, 22*.

15 Degórski, Wstęp, s. 16-17.

16 Jelonek, Hieronim, s. 76-77.

17 Hieronymus, Ep. 3, 5, s. 9*-10*; 16, 2, s. 40*-41*. 
późniejsze doświadczenia oraz zadania Strydończyka związane z pracą u boku papieża Damazego czy też jego kontakty z wielkimi teologami chrześcijańskiego Wschodu. Niejednokrotnie mówi się o pewnej tajemnicy tej egzystencji kryjącej się i zarazem wyjaśniającej w Piśmie Świętym. Wchodząc na biblijną drogę poznania Jezusa Chrystusa, Hieronim nie reprezentuje postawy chłodnego, dbającego przede wszystkim o zbliżający do obiektywnej prawdy dystans uczonego. Podchodząc do ,gorejącego krzewu", szybko poznaje cenę trawiącego ognia, którym jest dla niego Jezus. Już nie tylko coraz lepiej poznawany i rozumiany, ale przede wszystkim przeżywany. Na tej drodze mistyczne doświadczenia są zaledwie jednym z środków. Utwierdza się w przekonaniu, że mniszy tryb życia, pustynne otoczenie pozwalają kroczyć śladami Jezusa, do którego nie tylko zbliżają, ale wprost z Nim łączą post, umartwienie i modlitwa ${ }^{18}$. Ugruntowujące to przeświadczenie studium Biblii, pochłanianie wszystkich służących temu dostępnych dzieł (uważa się, że musiał przeczytać wszystkie ważne w jego czasie prace) i żarliwe gromadzenie umożliwiającej to wiedzy zdają się potwierdzać wybraną drogę osobistego wyrzeczenia i umartwienia. I tak drogą Hieronima staje się droga Chrystusa podnoszącego w swoim krzyżu człowieka do siebie, jednoczącego się z nim, wywyższając byt ludzki aż do niebios. W tej perspektywie wszystko, co ziemskie i doczesne, okazuje się zasługującą na pogardę marnością. Podobnie jak kruche, doczesne życie w obliczu tego, darowanego człowiekowi w śmierci Chrystusa ${ }^{19}$. Tyle tylko, że wymaga ono nie znajomości Chrystusa, jak najbardziej rozległej wiedzy o Nim, ale życia jak Chrystus, czyli - jak to rozumiał Hieronim - na pustyni, pełnego wyrzeczeń, umartwień oraz cierpien ${ }^{20}$. Stąd Strydończyk w swoich tekstach nie tyle naucza, jak żyć, ile raczej przelewa na papier własne doświadczenia duchowych zmagań, które nie są wolne od pokus, trudności i niepowodzeń. Niemniej jako przyjęte przez Chrystusa zostają nagrodzone „dotykaniem” uszczęśliwiającej nadprzyrodzoności w pełnej utrapień doczesności, co stanowi podstawę całej jego teologii życia duchowego.

$\mathrm{W}$ tej chrystocentrycznej perspektywie wypada zwrócić uwagę na dwie dość istotne cechy tej teologii. To po pierwsze wspomniane już osobiste doświadczenia i przeżycia Hieronima oraz będące ich konsekwencją wybory doktora Kościoła. Opisując własne nieszczęścia, tudzież radości i zwycięstwa, chce przekazać to, co wydaje mu się najbardziej prawdzi-

18 Chauffin, Święty Hieronim, s. 31.

19 Origene - Girolamo, 74 omelie sul Libro dei salmi, ed. G. Coppa, Milano 1992, s. $40-41$.

20 Hieronymus, Ep. 22, 7, s. 86*; J. Czuj, Św. Hieronim. Żywot - dzieła. Charakterystyka, Warszawa 1954, s. 9. 
we, sprawdzone, ale i skuteczne w przekonywaniu drugich, niekiedy opornych lub przesadnie wątpiących ${ }^{21}$. Pisząc zatem o swoich zmaganiach, stara się pomóc innym w lepszym zrozumieniu drogi wyrzeczenia i pokuty. Nie stawia przy tym siebie jako wzoru i źródła nauki, ponieważ jedynym wzorem i źródłem - zgodnie z jego chrystologiczną perspektywą - jest Jezus ${ }^{22}$. I po drugie głębokie przekonanie autora o tym, że wejście na drogę świętości jest równoznaczne $\mathrm{z}$ wejściem na drogę wyrzeczenia, umartwienia i postu jako najlepszych sposobów naśladowania Chrystusa ${ }^{23}$. Przy czym świętości i właściwych jej wymagań pozwalających jednoczyć się ze Zbawicielem Strydończyk nie uważał za zarezerwowaną tylko dla niektórych, wybranych lub tych, którzy sami sobie takie życie wybierają, uznając każdą inną drogę za równie dobrą. Nie tylko ukazuje ją jako możliwą dla wszystkich oczekujących życia wiecznego i uznających w Jezusie Chrystusie Zbawiciela, ale wprost konieczną ${ }^{24}$. Swiadczą o tym na przykład jego zachęty, zalecenia i wskazania, formułowane niejednokrotnie jak wymagania, co widoczne jest chociażby w jego pochwale dziewictwa i wdowieństwa w stosunku do małżeństwa.

W przywoływanym już w tym tekście liście do Eustochium, córki Pauli, Hieronim jednoznacznie stwierdza, niejako dzieląc się osobistym doświadczeniem, że dla kochających nic nie jest zbyt trudne, nic nadmiernie uciążliwe. Sięgając do biblijnej historii Jakuba wypełniającego wyjątkowo ciężkie zobowiązanie za żonę Rachelę ( $\mathrm{Rdz} 29,20)$, wzywa: „Kochajmy i my Chrystusa, zawsze szukajmy Jego objęć, a wszelka trudność wyda się łatwa. Za krótkie będziemy uważali wszystko, co jest długie"25. I odwrotnie, umartwienia, posty, wyrzeczenia, znoszone utrapienia, a także niedogodności wydadzą się twarde oraz trudne do zniesienia tym, którzy Chrystusa nie kochają. Wolność odzyskują ci tylko, którzy współumarli z Panem, ukrzyżowali swoje ciało wraz z namiętnościami i pożądaniami, aby z Chrystusem powstać i dostrzec marność wszystkiego pod słońcem. Przy czym Hieronim nie osłabia ceny miłości, w żadnym sensie wielkiego zobowiązania nie bagatelizuje, ukazując jako odpowiednie na miarę wezwania i powołania. Jedynie godną odpłatą za krew Odkupiciela jest krew odkupionych, chętnie oddających życie za Chrystusa. Posługuje się przy tym przykładami zarówno ze Starego, jak i Nowego Testamentu świadczącymi o walce i cierpieniu, poprzedzających zwycięstwo i chwałę ${ }^{26}$. Wyrzeczenie i ofiara są więc na miarę miłości

\footnotetext{
21 Hieronymus, Ep. 60, 16, s. 92*; 22, 30, s. $103 *-104 *$.

22 Hieronymus, Ep. 22, 23, s. 97*; 118, 7, s. 35*.

23 Hieronymus, Ep. 118, 4, s. 32*.

24 Hieronymus, Ep. 118, 5, s. 34*.

25 Hieronymus, Ep. 22, 40, s. 111*.

26 Hieronymus, Ep. 22, 39, s. 110*-111*.
} 
do Chrystusa, którego miłość pozostaje najważniejszym kryterium chrześcijańskiego życia, jedynym słusznym odniesieniem w praktykach pobożnościowych i w świadczeniu miłosierdzia potrzebującym. Toteż obdarowanie nawet bardzo wielu, szlachetne zaradzanie ich potrzebom w duchu chrześcijańskiej miłości nie spełnia wymagań tego kryterium. Ostatnim bowiem w rozumieniu Strydończyka w wojsku Chrystusa jest ten, kto siebie samego Chrystusowi nie potrafi oddać ${ }^{27}$, ofiarować nie tylko to, co zewnętrzne, ale to, co najbardziej własne, czego nikt, nigdy i nigdzie nie może odebrać, oddając się bez reszty ${ }^{28}$. W świetle tego samego kryterium Strydończyk interpretuje wyzdrowienie z ciężkiej choroby Blezyli, pisząc do Marceli. Sam Chrystus przyszedł do niej i dotykając jej ręki, podnosi ją (z choroby), aby teraz żyła tylko dla Niego i powstawszy, Jemu usługiwała (Mk 5,40) ${ }^{29}$.

\section{Chrystologiczne kryterium oceny doczesności i właściwych jej dóbr w perspektywie eschatologicznej}

Nie chodzi jednak tylko o ziemskie, doczesne życie i cieleśnie rozumiane uzdrowienie ani w tym tylko wymiarze rozumianą służbę Chrystusowi. Niewątpliwie jest ono konieczną drogą do zbawienia, umożliwiającą post i wyrzeczenie, jak również umartwienie i ofiarę, najlepiej otwierające na zrozumienie wiecznej szczęśliwości. Hieronim bowiem, w swoim ascetycznym wychyleniu w kierunku wieczności, podobnie jak nie osłabia ceny miłości, nie osłabia również realizmu doczesności, stworzonego przez Boga z miłości świata, aby mogło już w nim pojawić się Królestwo Boże. Niemniej ten sam Hieronim z naciskiem podkreśla, że doświadczający tego królestwa już na ziemi nie mają tutaj trwałego mieszkania. Żyją w ciele i wprawdzie w ich cielesności, a nie poza nią, pojawia się na ziemi Królestwo Boże, ale właśnie po to, aby - jak pisze Strydończyk w liście do Heliodora - nie żyli oni według ciała ${ }^{30}$. Zycie takie, zakrojone i zorientowane na to tylko, co doczesne, materialne, jest tak naprawdę poddane śmierci, znikomości, ponieważ człowiek przemija jak kwiat polny i trawa. Dlatego komentując Ewangelię według św. Mateusza, zaleca uwolnienie się od zbytniej troski o doczesny pokarm i ubiór, aby skuteczniej zabiegać o szatę

\footnotetext{
27 Hieronymus, Ep. 118, 5, s. 33*-34*.

28 Hieronymus, Ep. 118, 3, s. 31*.

29 Hieronymus, Ep. 38, 2, s. 161*.

30 Hieronymus, Ep. 60, 3, s. 83*.
} 


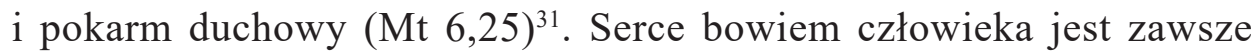
tam, gdzie jest jego skarb, to, co uznaje za największą i najcenniejszą wartość (Mt 6,21). Stąd bogiem żarłoka pozostanie brzuch ${ }^{32}$. W tym kontekście porównanie przez Jezusa Królestwa niebieskiego do skarbu ukrytego w roli, który odnaleziony zostaje ponownie ukryty (Mt 13,44), Hieronim rozumie jako odnalezienie Chrystusa i ponowne ukrycie Go w swoim sercu, co jest wystarczająca przyczyną okazywanej pogardy wszystkim korzyściom i dobrom tego świata ${ }^{33}$. One bowiem, a także ludzka natura i wszystko, co przeżywamy bez Chrystusa, jest tylko nędzą, próżnością ${ }^{34}$. Z Chrystusem i w Chrystusie natomiast również codzienne umieranie, cierpienie i doświadczanie znikomości, marności oraz kruchości tego świata odnajduje swój sens. Staje się drogą, i to zasługującą na wieczną chwałę. Dzieje się tak ze względu na - wyeksponowane już w tym tekście - znaczenie, jakie autor Wulgaty przyznaje miłości łączącej człowieka z Chrystusem, nadającej wartość codziennemu umieraniu ${ }^{35}$. Dzięki tej miłości, jak zauważa Hieronim w tym samym liście, człowiek nie musi żyć i podejmować codziennych trudów, związanych z nimi wyrzeczeń z myślą o kładącej się na wszystkich ludzkich dokonaniach śmierci. Nawet umierając, może myśleć o życiu na podstawie miłości wiążącej go z Chrystusem, będąc pewnym zwycięstwa. W takiej optyce ani długość ludzkiego życia, ani jego doczesny dostatek, jakiekolwiek bogactwa i zaszczyty, nie mają większego znaczenia. Prawdziwą wartość odnajdują w miłości Chrystusa, także gdy okazują się chwilą i prochem. Podobnie jak wszelką wartość i znaczenie tracą bez Chrystusa, choćby człowiek zabiegał o nie i traktował jako największe dobro ${ }^{36}$.

Jak wynika z treści przywoływanego już listu do Juliana, w naznaczonej znikomością i marnością doczesności Hieronim odkrywa potrzebne mu do wzmocnienia jego tez znaczenie symboliczne pozwalające uwydatnić powszechne poczucie i zarazem pragnienie sprawiedliwości. Odnosząc się do zarysowanego przez Chrystusa obrazu o okrytym purpurą bogaczu i pokrytym wrzodami Łazarzu oraz ich przyszłości (Łk 16,19), uznaje za niemożliwe używanie dóbr obecnych, ziemskich, związanych z nimi rozkoszy, radości z pierwszeństwa przed drugimi, pogardzanymi i skrajnie ubogimi,

31 Hieronymus, Commentarii in Evangelium Matthaei 6, 25, tł. J. Korczak, ŹMT 46, Kraków 2008, s. 35.

32 Hieronymus, Commentarii in Evangelium Matthaei 6, 21, s. 34.

33 Hieronymus, Commentarii in Evangelium Matthaei 13, 44, s. 90.

34 Hieronymus, Ep. 60, 13, s. 89*.

35 Hieronymus, Ep. 60, 19, s. 93*-94*.

36 Hieronymus, Ep. 60, 14, s. 90*. 
oraz dóbr przyszłych, niebieskich ${ }^{37}$. Nie można być - podkreśla z kolei w liście do mnicha Heliodora - współdziedzicem Chrystusa i dziedzicem tego świata, ponieważ doskonały sługa Chrystusa także na tym świecie nie posiada nic prócz Chrystusa ${ }^{38}$. Słabe ciało, ulegające wprawdzie rozkładowi, zmieniające się w popiół, właśnie dzięki Chrystusowi, Jego łasce może się oprzeć władcy tego świata, wszystkim wyrafinowanym pokusom i zasadzkom. Słabość, kruchość i znikomość mogą się okazać skutecznym narzędziem i środkiem $w$ walce $z$ największym przeciwnikiem człowieka, jeśli tylko złoży on swoją nadzieję w Chrystusie i z Nim zwiąże swoje oczekiwania. Zwłaszcza że doczesność określa Hieronim jednoznacznie jako miejsce zmagań, decydujących o przyszłości zawodów, walki o prawdziwą, wiecznie trwałą nagrodę. Ubiegający się o nią i zmagający z o wiele silniejszym od człowieka przeciwnikiem nie mogą się tu czuć bezpiecznie, nie powinni się spodziewać wytchnienia i pokoju, gdyż nikt nie kroczy bezpiecznie w krainie węży i skorpionów ${ }^{39}$. Kontestowany przez autora listu do Gaudencjusza sposób życia nastawiony na zdobycie, zapewnienie sobie w doczesnej rzeczywistości jak największych dóbr, jakby człowiek miał tu żyć wiecznie, i korzystanie z nich tak, jakby to życie za chwilę miało się skończyć, nie odpowiada sytuacji właściwego ziemskiej egzystencji zagrożenia. Nie wytrzymuje poza tym krytyki płynącej ze sposobu i stylu życia Chrystusa na tym świecie utożsamiającego się z biednymi i ubogimi, umierającego pod drzwiami domów, w których złotem błyszczą ściany, stropy, kapitele kolumn ${ }^{40}$.

Gromadzenie bogactw $\mathrm{w}$ takiej perspektywie to tylko daremny trud przysparzający człowiekowi $\mathrm{w}$ warunkach ziemskiej egzystencji najeżonej zmaganiami i niebezpieczeństwami dodatkowych utrapień. Zwłaszcza że człowiek nic z tego ze sobą nie zabierze i nic nie ocali. Nagromadzone dobra, niejednokrotnie za bardzo wysoką cenę, w wielkim trudzie i cierpieniu, jeśli pozostaną, to przypadną komuś innemu. Sięgając do starotestamentowego autora, Hieronim nazywa to „marnością nad marnościami” (Koh 1,2-3) ${ }^{41}$. Szczególnie kiedy takowy trud i zatroskanie nie pozwalają zdobyć tego, co służyłoby życiu przyszłemu (Koh 12,6-8) ${ }^{42}$. Strydończyk zaleca zatem takie życie, które - mimo znikomości i kruchości na tym świecie - może się zrealizować w pełni. To po prostu życie, jak zauważa w liście

37 Hieronymus, Ep. 118,6 , s. $34 *-35 *$.

38 Hieronymus, Ep. 14, 4-6, s. $31 *-33 *$.

39 Hieronymus, Ep. 22, 3, s. 83*.

40 Hieronymus, Ep. 128, 5, s. 181*.

41 Hieronim, Commentarius in Ecclesiasten 1, 2-3, tł. K. Bardski, BOK 5, Kraków 1995, s. 26-27.

42 Hieronymus, Commentarius in Ecclesiasten 12, 6-8, BOK 5, s. 147-148. 
do Teodory i zgodnie z wcześniejszymi wynurzeniami, z Chrystusem, przebywanie w Jego miłości ${ }^{43}$. Taki sposób życia zgodny jest przede wszystkim z zakreślonym przez samego Jezusa programem, stopniowo rozwijanym we wszystkich wyartykułowanych przez Niego przypowieściach zamkniętych - jak pisze w Komentarzu do Ewangelii wedtug św. Mateusza Hieronim sentencją. Zgodnie $\mathrm{z}$ nia $\mathrm{w}$ pracy $\mathrm{w}$ winnicy i w budowaniu domu, na uczcie weselnej ważny jest nie początek, ale koniec (Mt 22,14) ${ }^{44}$. Zacząć bowiem potrafi wielu, ale dojść do szczytu tylko niewielu. Wszyscy wprawdzie biegną, ale tylko jeden otrzymuje nagrodę (1Kor 9,24). Tak zatem należy biec, aby ją na końcu otrzymać ${ }^{45}$. „I ani bogactwu nie szkodzą dostatki, jeśli ich dobrze używa, ani niedostatek nie czyni ubogiego więcej godnym pochwały, jeśli wśród łachmanów i ubóstwa nie wystrzega się grzechów”"46. „W jedwabiu i w łachmanach panuje ta sama żądza" ${ }^{\text {"47 }}$. Program ten, w innym swoim komentarzu, nasz autor nazywa prawdziwie udaną inwestycją, niczym „dawanie na lichwę" wystarczająco się thumaczące, ponieważ niezwiązane $\mathrm{z}$ czyjąkolwiek krzywdą lub stratą. To jakby rzucanie ziarna w dobrze przygotowaną, nawodnioną obficie ziemię gwarantującą otrzymanie w dniu sądu o wiele więcej, niż się zainwestowało. Prawem tej inwestycji jest dzielenie się z ubogimi (Koh 11,1) ${ }^{48}$.

Perspektywa wieczności i podporządkowany jej program pozwalają właściwie ocenić dobra doczesne i poprawnie kształtować ziemską egzystencję, co Strydończyk uznaje za prawdziwą mądrość. Obok wyrzeczenia i postu skuteczną do niej drogą jest również kontemplacja pozwalająca już tu na ziemi doświadczać prawd wiecznych, „których wartość przetrwa również w niebie"49. Do tych prawd wiecznych przybliża także mądrość pustelnika. Nie polega ona, tak jak w przypadku rzeczy materialnych, na uwolnieniu się od przywiązania. Wręcz przeciwnie, gdyż chodzi tu o rzeczy nieprzemijające i pozwalające uwolnić się od przemijających. Podobnie jak nie polega również na zaniechaniu czy choćby osłabieniu wartości ubóstwa i wyrzeczeń uznawanych przez autora Wulgaty za wartość wieczną i do tego bezcenną, umożliwiającą odróżnienie prawdziwej od fałszywej mądrości. Posiadający tę pierwszą, w przeciwieństwie do ulegających złudzeniu tej drugiej, dążą do oderwania się od ziemskiego życia po to, aby wieść życie piękniejsze, Boże. W ich oczach to wszyst-

\footnotetext{
43 Hieronymus, Ep. 75, 2, s. 190*.

44 Hieronymus, Commentarii in Evangelium Matthaei 22, 14, s. 155.

45 Hieronymus, Ep. 71, 2, s. 170*.

46 Hieronymus, Ep. 79, 1, s. 235*.

47 Hieronymus, Ep. 79, 10, s. 243*.

48 Hieronymus, Commentarius in Ecclesiasten 11, 1, BOK 5, s. 134.

49 Hieronymus, Ep. 53, 10, s. 35*.
} 
ko, o co zabiegają ludzie powodowani fałszywą mądrością, nie ma żadnego znaczenia ${ }^{50}$. Wygłoszona przez Hieronima pochwała tej prawdziwej mądrości nie pozwala mu na odmówienie jakiejkolwiek wartości światowej ambicji i potrzebie oglądania czegoś wspaniałego. Mogą one bowiem pomagać posiadającym tę wieczną, Bożą mądrość, przynaglać do wstępowania myśla do raju, bycia tym, kim będzie się kiedyś, czego doczesne dobra i światowa ambicja są tylko cieniem, niedoskonałą zapowiedzią ${ }^{51}$. Powtarzane za Eklezjastesem słowa „marność nad marnościami” oprócz znaczenia całkowitej znikomości wszystkiego na tym świecie posiadają także swoje znaczenie symboliczne pozwalające w perspektywie wieczności inaczej oceniać doczesność jako niepozbawioną wszelkiej wartości. „Płomyczek kaganka cieszy, dopóki nie wzejdzie słońce, w blasku którego bledną i gwiazdy" (Koh 1,2$)$ napisze Hieronim ${ }^{52}$. Z tego samego powodu marnością jest również radość i dobro (Koh 2,1), także te „duchowe", dziś uchodzące za wystarczającą wartość, aby zostawić dla niej wszystko inne - materialne. Kiedy zostana objawione twarzą w twarz i w pełni ukaże się ich obecna znikomość, zostanie niejako obnażone nasze dotychczasowe widzenie jakby w zwierciadle i zagadce ${ }^{53}$ opanowujące pozbawionych owej Bożej mądrości. Tylko w jej świetle człowiek nienawidzi życia na tym świecie, bo w porównaniu z rajem i błogosławieństwem życia przyszłego jest ono zesłaniem, więzieniem i łez doliną $(2,17)^{54}$, co otwierającym się na Bożą mądrość objawione zostało już w Starym Testamencie: „I wróci proch do swej ziemi, tak jak był nią przedtem, a duch powróci do Boga, który go dał" $(12,6-8)^{55}$. Słowom Epikura „niech je i pije, używa, kto spodziewa się śmierci, ponieważ nic nie ma po śmierci; śmierć jest niczym" Hieronim przeciwstawia życie chrześcijanina, którego ojczyzna jest w niebie ${ }^{56}$. Powołując się na Pismo Święte, zgodnie z którym w królestwie będzie największy i najmniejszy, uzasadnia to różnym stopniem zasług, co nie ujawnia się w pełni na ziemi, ale dopiero w wieczności po sądzie ${ }^{57}$.

\footnotetext{
50 B. Degórski, Wstęp, s. 27.

51 Hieronymus, Ep. 22, 41, s. 112*-113*; 130, 14, s. 203*-204.

52 Hieronymus, Commentarius in Ecclesiasten 1, 2, BOK 5, s. 26-27.

53 Hieronymus, Commentarius in Ecclesiasten 2, 1, BOK 5, s. 38.

54 Hieronymus, Commentarius in Ecclesiasten 2, 17, BOK 5, s. 48.

55 Hieronymus, Commentarius in Ecclesiasten 12, 6-8, BOK 5, s. 147-148.

56 Hieronymus, Adversus Iovinianum II 7, w: Hieronim, Pisma polemiczne: Przeciw Helwidiuszowi; Przeciw Jowinianowi; Przeciw Wigilancjuszowi, tł. W. Kania-L. Nieścior - G. Rurański, Tyniec 2013, s. 297-302.

57 Hieronymus, Adversus Iovinianum II 26-28, s. 355-361.
} 


\section{Post i umartwienie jako skuteczne zabezpieczenie przed odrzuceniem Chrystusa}

Nie każdy jednak osiągnie szczęśliwą wieczność, podobnie jak nie każdy na tym świecie posiada Bożą mądrość - utrzymuje Hieronim. Zależna jest ona nie tylko od łaski Zbawiciela, ale również od ludzkiego życia ${ }^{58}$. Chrystus wyprze się tych, którzy zaparli się Jego. Realizm potępienia w pismach Hieronima jest równie obecny jak nadzieja zbawienia, co zdaje się potwierdzać wspomniany powyżej opis doczesnej rzeczywistości jako pełnej niebezpieczeństw i bardziej odpowiadającej walce niż egzystencji w pokoju. I tak jak do poznania prawdy i tym samym Bożej mądrości, przybliża miłość do Chrystusa, tak też według Hieronima oddala od niej dostatnie i niekontrolowane życie. Mimo że i ta cena miłości Chrystusa, jaką jest męczeństwo, nie jest jego zdaniem wygórowana, to zgodnie $\mathrm{z}$ duchem $\mathrm{czasu}^{59}$ nie myśli on tylko o męczeństwie, ale o codziennym życiu, w którym każdy grzech, a nawet niedoskonałość, jest wypieraniem się Boga ${ }^{60}$. Najbardziej skutecznym sposobem uniknięcia zaparcia się Chrystusa natomiast jest zapieranie się siebie, wejście na drogę pokuty i wyrzeczenia ${ }^{61}$.

Ponownie zatem wraca problem jednorazowej decyzji i początku, nawrócenia. Słowa Jezusa o konieczności dźwigania krzyża na co dzień (Mt 10,38) Hieronim interpretuje jako nieodzowną gotowość na wyrzeczenie przez całe życie i możliwość uczenia się miłości Chrystusa zawsze, w czym jednorazowy, choćby najbardziej radykalny zwrot, podyktowany nawet bardzo gorącym ogniem wiary, nie wystarczy ${ }^{62}$. Aby nie oglądać się po takiej decyzji wstecz i nie narażać na stale zagrażające człowiekowi w doczesności ryzyko powrotu do dawnych grzechów, trzeba - jak napisze Strydończyk - pozostać na dachu cnót, nigdy z niego ani na chwilę nie schodzić, co rozumie jako nieustanną gotowość sprostania bardzo wysokim wymaganiom ${ }^{63}$. Autor Wulgaty stara się przy tym unikać jednostronno-

58 Hieronymus, Commentariii in IV epistulas Paulinas. Ad Titum 2, 11-14, 586BD, w: Ambrozjaster, Hieronim, Pelagiusz, Komentarze do Listu św. Pawła do Tytusa, tł. A. Baron, Kraków 2003, s. 169-170.

59 W czasach Hieronima ustały prześladowania - przynajmniej na taką skalę, jak to miało miejsce wcześniej. Dlatego praktykowana i zalecana pokuta staje się elementem zastępującym dotychczasową zasługę z powodu prześladowań.

60 Hieronymus, Commentariii in IV epistulas Paulinas. Ad Titum 1, 16, 576D-577A, s. $156-157$.

${ }_{61}$ Hieronymus, Commentariii in IV epistulas Paulinas. Ad Titum 1, 16, 577BC, s. 156.

62 Hieronymus, Commentarii in Evangelium Matthaei 10, 38, ŹMT 46, s. 61.

63 Hieronymus, Ep. 71, 1, s. 170*. 
ści. Niekwestionowane przez niego pierwszeństwo wymiaru duchowego, uwypuklone chociażby w jego Komentarzu do Eklezjastesa, na co zwracaliśmy uwagę, kończąc poprzedni paragraf, nie przysłania w żadnym sensie pełnego obrazu Chrystusa. Zgodnie z tym obrazem Zbawiciel jest cielesny i duchowy, boski, ale i ludzki. Dlatego człowiek, otwierając się na właściwą Bogu wieczność, dąży do niej przez doczesność. Analogicznie zatem nie wystarcza tylko wewnętrzne opowiedzenie się za Bogiem. Musi być ono potwierdzone także zewnętrznie, przez dobre czyny (w rozumieniu Hieronima pokutne), co odzwierciedla wnętrze i serce oddane tylko Bogu $^{64}$. Troskę o zrównoważenie swoich tez można dostrzec w Komentarzu Strydończyka do Księgi Jonasza, co rozumie jako głoszenie pełnej prawdy o Bogu. Mówiąc więc o miłosierdziu Boga, nie zapomina o surowym Jego sądzie. Jak przekonuje, zatrzymując się tylko na tym pierwszym, nie skłoniłby nikogo do surowej pokuty. Z kolei ukazując Boga jako okrutnego sędziego, nie powiedziałby prawdy o Jego naturze ${ }^{65}$. A wszystko po to, aby - jak napisze w jednym ze swoich listów - już w doczesności przygotowywać sobie szczęśliwą wiecznośćc6.

Kwestie te Hieronim rozwija zwłaszcza w swoich listach ascetycznych ${ }^{67}$. Wprawdzie trudno je jakoś kategorycznie odróżniać od innych, ponieważ właściwe im tematy obecne są także w tzw. nekrologach i listach pocieszających $^{68}$. Ale to $\mathrm{w}$ nich właśnie pisze wiele o życiu pustelniczym, umartwieniu, pokucie, życiu klasztornym, o tym również, że każde wyrzeczenie, zwłaszcza cierpienie, codzienne męczeństwo będzie nagrodzone chodzeniem w białej szacie z Barankiem ${ }^{69}$. Ponoszenie trudów jest konsekwencją przyrzeczenia danego Chrystusowi na chrzcie. Jedyną zatem formą miłości - jak napisze - jest okrucieństwo ${ }^{70}$. I właśnie „okrucieństwo miłości”, zrozumiałe i możliwe do przyjęcia tylko dla tych, którzy ze wszystkiego najbardziej obawiają się utraty Chrystusa, odrzucenia Jego miłości, dyktuje naszemu autorowi bardzo surowe wymagania, będące świadectwem jego głęboko ascetycznego życia, wobec adresatów swoich pism. Tylko w tej perspektywie szczególnie surowa pokuta może być traktowana

64 Hieronymus, Commentariii in IV epistulas Paulinas. Ad Titum 1, 15, 576BC, ŹMT 28, s. 155 .

65 Hieronymus, Commentariorum in Ionam prophetam liber unus 4 (3), tł. L. Gładyszewski, ŹMT 8, Kraków 1998, s. 132.

66 Hieronymus, Ep. 108, 3, s. 160*-161*.

67 Czuj, Św. Hieronim. Żywot-dzieła, s. 60-78.

68 Czuj, Św. Hieronim. Żywot-dzieła, s. 42-60.

69 Hieronymus, Ep. 14, 4, s. 31*.

70 Hieronymus, Ep. 14, 2, s. 29*-30*. 
jako „deska ratunku” "11. Wszelka zaś słodycz w warunkach nieustannie czyhających na człowieka niebezpieczeństw może się okazać gorzką trucizną. Dlatego, zauważa, w ofiarach Pańskich nie składa się miodu, a w świątyni Pańskiej zapala się oliwę wyciskaną z gorzkich oliwek, ponieważ nawet wosk będący „mieszkaniem miodu” został wzgardzony. Paschę spożywa się z gorzkimi przyprawami, w przaśnikach sprawiedliwości i prawdy. Ten, kto je osiągnie, będzie na świecie znosił prześladowania ${ }^{72}$. W tym samym duchu komentuje fragment tekstu z Ewangelii według św. Mateusza, kiedy tłumaczy znaczenie „ciasnej” i „przestronnej bramy” (7,13-14). Bramę przestronną interpretuje jako rozkosze tego świata, o które ludzie się ubiegają, ciasna natomiast jest symbolem trudów i postów ${ }^{73}$. Na próbę bowiem, zwłaszcza trudną, na pokuszenie duszę należy przygotować przez post i wyrzeczenie $(4,4)^{74}$.

Przeplatając bardzo często swoją argumentację obszernie cytowanymi fragmentami zarówno ze Starego, jak i Nowego Testamentu, ukazuje pokutę jako jedyna drogę do Bożego miłosierdzia i przebaczenia, niezależnie od ciężaru popełnionej winy ${ }^{75}$. Pisząc do Rustyka, maluje obraz ,wspaniałych kwiatów, zerwanych na pięknych łąkach Pisma, aby jako wieniec pokuty, włożyć go na głowę"76. Ten niestrudzony miłośnik Pisma Świętego, ze względu na miłość i zażyłość z Chrystusem, jest przekonany, że wszystko, co ważne dla człowieka w perspektywie zbawienia, zachowania łaski odkupienia, zawarte jest w Biblii. W niej znajdują się wszystkie wskazania i pouczenia, jaką należy kroczyć drogą, a jakiej unikać i co czynić, aby nie błądzić, nie schodzić na bezdroża. Autor Wulgaty nie ukrywa jednak, że dotarcie do tej wiedzy i właściwego rozumienia zawartych w Piśmie Świętym prawd wymaga trudu ${ }^{77}$. Odnosząc się do Księgi Koheleta, przekonuje, że mądrość przychodzi przez udręki, nieznośne trudy, a medytacja i studiowanie to ciężkie, nieznośne jarzmo $(\text { Koh } 1,18)^{78}$. Dlatego pracę umysłową, którą tak sobie cenił i pielęgnował w swoim wyborze ascetycznego i pełnego wyrzeczeń życia na pustyni, uznawał za wyjątkowo skutecznie niszczącą niskie skłonności ludzkiej natury ${ }^{79}$, mimo to niewystarczającą. Ukazując ją więc jako nieodzowną, a intelektualny wysiłek jako bardzo pożyteczny, czynił to

\footnotetext{
71 Hieronymus, Ep. 122, 4, s. 123*.

72 Hieronymus, Ep. 128, 2, s. 179*.

73 Hieronymus, Commentarii in Evangelium Matthaei 7, 13-14, ŹMT 46, s. 38.

74 Hieronymus, Commentarii in Evangelium Matthaei 4, 4, ŹMT 46, s. 20-21.

75 Hieronymus, Ep. 122, 1-3, s. 115*-121*.

76 Hieronymus, Ep. 122, 4, s. $122 *-123 *$.

77 Hieronymus, Ep. 58, 9, s. 75*.

78 Hieronymus, Commentarius in Ecclesiasten 1,18, BOK 5, s. 37-38.

79 Degórski, Wstęp, s. 14
} 
w perspektywie pokuty i wyrzeczenia. Jak napisze w Komentarzu do Księgi Jonasza, przed odbyciem pokuty trudno dostrzec różnicę między dobrem a złem, między prawicą a lewicą (Jon 4,10-11) ${ }^{80}$. Władcy, królowie, szlachetnie urodzeni, bogaci i jeszcze bardziej ludzie wymowni trudniej przyjmują wiarę i nawracają się, ponieważ są zaślepieni przez bogactwo i przepych, ulegaja wadom oraz nie potrafia dostrzec $\mathrm{cnót}^{81}$.

Wiele miejsca Strydończyk poświęca w swoich tekstach prostym pokarmom, jako pożywieniu ludzi bogobojnych, ponieważ „należy zabiegać, aby tych, których sytość wygnała z raju, sprowadziła tam na powrót wstrzemięźliwość" 82 . W innym swoim liście przypomni, że Ewa została wyrzucona z raju z powodu pokarmu, a Eliasz, który 40 dni ćwiczył się w poście, na wozie ognistym zostaje porwany do nieba. Mojżesz 40 dni karmił się tylko zażyłą rozmową z Bogiem, zaś Jezus po 40 dniach postu był kuszony pokarmem: „Jeśli jesteś Synem Bożym, powiedz aby te kamienie stały się chlebem"83. W tej perspektywie ocenia chrześcijańską pobożność, która nie powinna koncentrować się i wyrażać w kosztownym ozdabianiu świątyń. „Jaki pożytek z tego - napisze - że ściany błyszczą drogimi kamieniami, a Chrystus w ubogim cierpi głód. A przecież to ludzka dusza jest prawdziwą świątynią Chrystusa. Ją ubieraj i obsypuj podarunkami" ${ }^{4}$. Zaleca niewyszukane potrawy, poszukując potwierdzenia swoich słów w Ewangelii i przywołując obraz uczniów Jezusa zrywających kłosy, gdy zaczęli odczuwać głód (Mt 12,1). Nie szukają przygotowanych posiłków, lecz prostego pokarmu, poprzestając na tym, co zsyła niebo ${ }^{85}$. Poprzedzający na pustyni Jezusa Jan Chrzciciel nosi odzienie z sierści wielbłądziej, jego pokarmem jest szarańcza i miód leśny (Mt 3,4) ${ }^{86}$, co staje się dla Hieronima dowodem, że zarówno pokarm, jak i strój są godne pokuty, co wybrzmiewa dla niego równie mocno już na kartach Starego Testamentu (Jon 3,5). Uznając wór i post za skuteczną broń przeciw grzechom, wskazuje na pewną hierarchię, zgodną zresztą ze swoim najgłębszym przekonaniem o pierwszeństwie wymiaru duchowego, mimo wspomnianej troski o zachowanie równowagi ze względu na człowieczeństwo Jezusa. „Najpierw zatem post, a potem wór; najpierw to, co ukryte, potem to, co jawne. To pierwsze zawsze jest dla Boga, a drugie niekiedy bywa widoczne także dla ludzi. A jeśli z dwóch rzeczy koniecznych jedno trzeba by wybrać, to wybrałbym raczej post

\footnotetext{
80 Hieronymus, Commentariorum in Ionam prophetam liber unus 4 (11), ŹMT 8, s. 141.

81 Hieronymus, Commentariorum in Ionam prophetam liber unus 3 (6-9), ŹMT 8, s. 129.

82 Hieronymus, Ep. 22, 10, s. 88*.

83 Hieronymus, Ep. 130, 10, s. 200*-201*.

84 Hieronymus, Ep. 58, 7, s. 74*.

85 Hieronymus, Commentarii in Evangelium Matthaei 12,1, ŹMT 46, s. 71.

86 Hieronymus, Commentarii in Evangelium Matthaei 3,4, ŹMT 46, s. $18,65$.
} 
bez wora, niż wór bez postu" ${ }^{\text {"7 }}$. Jednoznacznie wskazuje w ten sposób na wyższość pokuty duchowej nad cielesną i jednocześnie skutecznie zabezpiecza się przed jakimkolwiek przejawem potępionej przez Jezusa obłudy, W związku z chęcią odbierania chwały od ludzi z powodu pokuty, a nie od Boga (Mt 6,2) ${ }^{88}$. Poszcząc zatem, należy wyglądać na radosnych i świątecznie, a nie posępnie i nędznie ${ }^{89}$.

Jakkolwiek trudno żyć bez pokarmu i służyć Bogu, podobnie jak bez okrycia poddanego postom i umartwieniu ciała, przy uważnej lekturze pism Strydończyka trudno przeoczyć dość istotne kryterium jednego i drugiego. Chodzi o zalecaną z wielką troską modlitwę i to w określonym czasie, o godzinie trzeciej, szóstej, dziewiątej, jutrznia, nieszpory. Bez uprzedniej modlitwy nie powinno się przyjmować pokarmu i odchodzić od stołu bez dziękczynienia Stwórcy. Dwa albo trzy razy należy wstawać w nocy i rozważać to, co za dnia, podczas lektury Pisma Świętego, utkwiło w pamięci. Ręka powinna czynić znak krzyża przed każdym krokiem i wszelką czynnością, aby post nie rodził gniewu i w ten sposób nie czynił większego zła niż jego brak ${ }^{90}$. W liście do Salwiny napisze: „Miej zawsze w rękach Boże książki i tak często odprawiaj modły, aby wszystkie strzały fantazji, które $\mathrm{z}$ reguły uderzają w młodość, odbijały się od tej tarczy"91.

\section{Naśladowanie Chrystusa przez dziewictwo i wdowieństwo w aspekcie chrześcijańskiego postu i wyrzeczenia}

Szczególną formą wyrzeczenia i zarazem naśladowania Chrystusa $\mathrm{w}$ pismach św. Hieronima jest dziewictwo i wdowieństwo, przy czym temu pierwszemu przyznaje znacznie większą rangę, a jedno i drugie zdecydowanie stawia przed małżeństwem. Nie znaczy to tym samym, że w jakikolwiek sposób deprecjonuje małżeństwo, ale - jak mocno podkreśla - rozróżnia dobre i lepsze, zasługujące na większe i mniejsze uznanie. Wybrzmiewa to zwłaszcza w jego polemice $z$ Jowinianem ${ }^{92}$ utrzymującym, że o sile moralnej chrześcijaństwa decyduje łaska chrztu

\footnotetext{
87 Hieronymus, Commentariorum in Ionam prophetam liber unus 3 (5), ŹMT 8, s. 125.

88 Hieronymus, Commentarii in Evangelium Matthaei 6, 2, ŹMT 46, s. 31.

89 Hieronymus, Commentarii in Evangelium Matthaei 6, 17, ŹMT 46 s. 34.

90 Hieronymus, Ep. 22, 37, s. 108*-109*.

91 Hieronymus, Ep. 79, 9, s. 242*-243*.

92 Hieronymus, Ep. 49, 2, s. 199*.
} 
i wiara, a nie czyny ascetyczne ${ }^{93}$. Omawiając ten problem w apologetycznym tekście do Pammachiusza broniącym ksiąg przeciw Jowinianowi, Strydończyk zwraca uwagę na stawiane przez swojego adwersarza na równi dziewictwa i małżeństwa oraz niedostrzeganie między nimi żadnej różnicy ${ }^{94}$. Odpowiadając na to, Hieronim posługuje się dość sugestywnym obrazem, pisząc: „W dużym domu są nie tylko rzeczy ze srebra i złota, ale również drewniane i gliniane; bardziej i mniej szlachetne, ale pierwszeństwo należy się dziewictwu"95, które w odróżnieniu od stanu małżeńskiego nie przeszkadza w modlitwie ${ }^{96}$. Wręcz przeciwnie, ponieważ jest szczególną formą naśladowania Chrystusa ${ }^{97}$. Zgodnie przy tym z zaleceniem Apostoła nakazującego modlić się nieustannie, co uznaje za niemożliwe do pogodzenia $\mathrm{z}$ obowiązkami małżeńskimi ${ }^{98}$. Dlatego nagroda - miejsce szczególne w królestwie niebieskim przeznaczone dla bezżennych nie może być też miejscem dla żonatych ${ }^{99}$. Koresponduje to wyraźnie z jego przywołanym powyżej przekonaniem o niemożliwości cieszenia się zaszczytami i obfitością zarówno w tym, jak i w przyszłym życiu. Nazywa wobec tego dziewictwo złotem, a małżeństwo - srebrem i nawiązując do cytujących Ewangelię łacińskich oraz greckich autorów, wymienia różny owoc: stokrotny, sześćdziesięciokrotny, trzydziestokrotny, ale rodzący się z jednej ziemi i z jednego nasienia ${ }^{100}$.

Na czym polega zatem istota dziewictwa, któremu Hieronim poświęca tak wiele uwagi i wyjątkowo ceni ten właśnie sposób zasługiwania na wieczną nagrodę ze względu na zjednoczenie z Jezusem? Otóż dość charakterystyczna u tego pisarza chrześcijańskiego jest, również w tym aspekcie, bardzo wyraźna i traktowana jako istotne kryterium perspektywa eschatologiczna. Mimo że w opracowaniach poświęconych autorowi Wulgaty problem ten jest dość rzadko podejmowany, wymiar eschatologiczny stanowi bezsprzecznie podstawę i zarazem wyjaśnienie jego bardzo surowych wymagań ascetycznych. W tej perspektywie Hieronim bliski jest św. Pawłowi oczekującemu rychłego, powtórnego przyjścia Chrystusa. Rzutuje to również na jego egzegezę odnoszącą się między innymi do dziewictwa oraz wdowieństwa i ich relacji do małżeństwa. „Czas eschatolo-

93 L. Nieścior, Wstęp, w: Hieronim, Pisma polemiczne. Przeciw Helwidiuszowi. Przeciw Jowinianowi. Przeciw Wigilancjuszowi, red. L. Nieścior, ŹM 67, Tyniec 2013, s. 94.

94 Hieronymus, Ep. 49, 2, s. 199*-200*.

95 Hieronymus, Adversus Iovinianum I 3, ŹM 67, s. 117-121.

96 Hieronymus, Adversus Iovinianum I 7, ŹM 67, s. 129-135.

97 Hieronymus, Adversus Iovinianum I 8, ŹM 67, s. 135-138.

98 Hieronymus, Ep. 22, 22, s. 96*.

99 Hieronymus, Adversus Iovinianum I 12, ŹM 67, s. 148-154.

100 Hieronymus, Ep. 49, 3, s. 201*. 
giczny" ${ }^{101}$ w przekonaniu naszego autora to nie tylko jakaś bardzo odległa i zupełnie zakryta przed ludzkimi wyobrażeniami tajemnica przyszłość. Choć tego wymiaru misterium Strydończyk nigdzie nie znosi i nie lekceważy, to bardzo wyraźnie podkreśla całkowicie nową sytuację człowieka po przyjściu Chrystusa niż ta, która miała miejsce przed wcieleniem. Jego zdaniem w Jezusie Chrystusie eschatologia nie tyle bardziej lub mniej uchyla swój dotychczasowy wymiar tajemnicy, ile raczej staje się teraźniejszością, wkracza w doczesność. Pozwala również właściwie rozumieć fragmenty ze Starego Testamentu chwalące bogactwo i małżeństwo, napisane na podstawie wprawdzie zapowiadanego, przewidywanego Chrystusa, jednak jeszcze nieobecnego: „Żaden żołnierz nie śpieszy w bój z małżonką. Uczeń, który chce pogrzebać ojca, nie uzyskuje pozwolenia" "102.

$\mathrm{W}$ takim rozumieniu sprawy tego świata, a wraz z nimi małżeństwo, nabiera zupełnie innej dynamiki. Po zmartwychwstaniu, w eschatologicznej rzeczywistości nie będzie związków małżeńskich ${ }^{103}$. Ale ta rzeczywistość w zmartwychwstałym i obecnym w Kościele oraz w świecie Jezusie Chrystusie już nas dotyczy. Poza tym jest szczęśliwa i wieczna, mimo rysującego się przed człowiekiem widma śmierci. A skoro tak, to warto - Hieronim nie waha się twierdzić, że nawet trzeba - tak żyć w doczesności, aby była już ona przedsmakiem, udziałem w wieczności. Jeśli takie życie bardzo dużo kosztuje, okazuje się niezwykle wymagające i trudne, to oznacza tylko niegotowość człowieka do życia wiecznego i niezrozumienie istoty śmierci, dopóty groźnej i kładącej się cieniem na wszystkich dokonaniach człowieka, dopóki nie zrozumie on wartości i znaczenia postu oraz wyrzeczenia i nie będzie do nich zdolny. Dopóki nie będzie zdolny do dziewictwa, którego pochwały nasz autor nie szuka tylko w Nowym Testamencie opisującym w gruncie rzeczy wejście eschatologii w Jezusie Chrystusie w doczesność, kiedy np. w Komentarzu do Ewangelii według św. Mateusza wyraźnie podkreśla nagrodę dla tych, którzy zdecydowali się być dziewiczy dla Chrystusa (Mt 19,11-12) ${ }^{104}$, ale również w Starym. Jak napisze wzmiankowanemu Jowinianowi, Adam i Ewa przed upadkiem zachowywali stan dziewiczy, a po upadku żyli w stanie małżeńskim. Wnioskuje na tej podstawie, że obraz Boga w człowieku nie odbija się w małżeństwie, ale w życiu na wzór dziewicze-

101 Hieronim bardzo dobrze zdaje sobie sprawę z niestosowności używania w opisywaniu eschatologicznej przyszłości terminów wyrażających kategorie przestrzenno-czasowe, podobnie jak fizyczne. Niemniej posługuje się ujęciami zakorzenionymi mocno w tradycji biblijnej i teologicznej ze względu na ich znaczenie symboliczne.

102 Hieronymus, Ep. 22, 21, s. 95*-96*.

103 Hieronymus, Adversus Iovinianum I 13, ŹM 67, s. 154-162.

104 Hieronymus, Commentarii in Evangelium Matthaei 19, 11-12, ŹMT 46, s. 131. 
go Chrystusa narodzonego z Dziewicy ${ }^{105}$. Przesądza to $\mathrm{w}$ zasadzie nie tylko o głębokim przeświadczeniu Hieronima o wyższości dziewictwa nad małżeństwem ${ }^{106}$, ale również o uznaniu dziewictwa jako bardziej naturalnego niż małżeństwo. Dlatego zamężnym kobietom przyznaje drugie miejsce po dziewicach: „Ewa była w raju dziewicą, a po obleczeniu się w skórzane szaty rozpoczęła życie małżeńskie. Dziewictwo jest więc rzeczą naturalną, a małżeństwo powstało po grzechu"107. Powołując się na Księgę Izajasza (Iz 1,21), małżeństwa nie zaleca, ale toleruje, gdyby okazało się, że ktoś dążąc do wyższych rzeczy, wybrałby dziewictwo, ale przez swoją słabość skończyłby w „czeluściach piekła”"108. Można w jego sformułowaniach doszukać się nawet rzekomej pochwały małżeństwa, co jest raczej obliczone na dość wymierny efekt, jakim jest tak naprawdę pochwała dziewictwa i tylko dziewictwa: „Chwalę zaślubiny, chwalę związek małżeński, ale dlatego, że mi rodzi dziewice; wybieram z cierni róże, z ziemi złoto, z muszli perłę. Czy ten, co orze, cały dzień będzie orał? Czy nie będzie się też cieszył z owocu swej pracy ${ }^{109}$ ?" W tym samym sensie należy rozumieć fragment listu do Pammachiusza, w którym pisze o zachowaniu przez siebie godności małżeństwa i wywyższeniu dziewictwa ${ }^{110}$.

Strydończyk jednak, zdając sobie sprawę z niepopularności swoich tez, także w jego czasach, okazuje się nieustępliwy i tłumaczy to najwyższym dobrem człowieka, posługując się argumentami biblijnymi, teologicznymi oraz egzystencjalnymi. Dlatego też wymagając zdecydowanie, nie nakazuje wszystkim dziewictwa i podkreśla jego zasługujący charakter. Jako ofiarowane i dobrowolnie przyjęte jest ono bowiem cenniejsze ${ }^{111}$. A kryterium takiej oceny jest, z punktu widzenia chrystocentryzmu Hieronima, dość oczywiste. Nie tylko powinno się wzgardzić małżeństwem i rodziną, ale wprost, jak napisze w liście do mnicha Heliodora, z miłości do Chrystusa trzeba. Zdaje sobie sprawę $\mathrm{z}$ tego, że brzmi to wprost okrutnie, ale takie okrucieństwo ukazuje jako jedyną formę miłości rodzinnej zrywającej $\mathrm{w}$ zasadzie więzy rodzinne $\mathrm{z}$ obawy przed piekłem, utratą miłości Boga. Stąd wszelkie przywiązanie, wstrząsające wiarą i rodzące niepokój, należy rozbić o mury Ewangelii ${ }^{112}$.

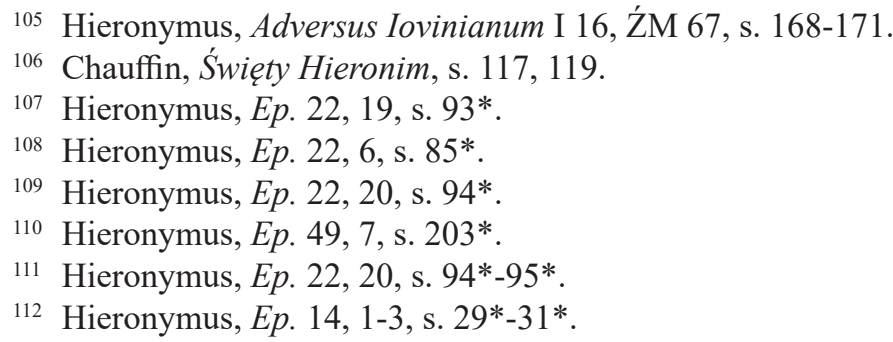


W przywoływanym już liście do Eustochium, córki Pauli na temat strzeżenia dziewictwa przytacza niewzruszone zasady, ostrzega przed zagrożeniami i wskazuje na sprzyjające okoliczności. Zgodnie ze swoimi wcześniejszymi rozstrzygnięciami w kwestii oceny duchowości i cielesności uznaje, nawiązując do ewangelicznej przypowieści o pannach roztropnych i nieroztropnych (Mt 25,1-12), za głupie i złe te wszystkie panny, które zachowują dziewictwo na ciele, ale nie w duszy ${ }^{113}$, gdyż miłość cielesną zwycięża duchowa miłość do Chrystusa ${ }^{114}$. Tego rodzaju niebezpieczeństwo zagraża zwłaszcza zbytnio liczącym na własne siły i lekceważącym lub podważającym wartość wyrzeczenia. Hieronim, służąc swoim doświadczeniem, radzi, aby dziewice wystrzegały się wina, które nazywa pierwszą i najgroźniejszą bronią w ręku szatana, potężniejszą niż pycha i pochlebstwo ${ }^{115}$. Czystość można uchronić tylko przez post i umartwienie - dodaje. Właściwie w taki właśnie sposób uzasadnia potrzebę wyrzeczenia. Nie jakoby sobie Bóg upodobał w „próżnym żołądku” i ,gorączce płuc", ale że tylko w taki sposób można uchronić czystość ${ }^{116}$. Najbardziej zatem skutecznym sposobem i najbardziej właściwą postawą w zachowywaniu dziewictwa jest codzienny post ${ }^{117}$. $Z$ kolei najbardziej niebezpieczne w stanie dziewictwa jest poszukiwanie próżnej chwały i uznania oraz pochwał ludzi z tego powodu, jak również pozostawanie wprawdzie pokorną i skromną, ale w tym tylko, co widać: „Suknia czarna, pasek zgrzebny i nogi brudne, a żołądek, ponieważ go nie widać, wrze od pokarmów"118.

Dziewicom Strydończyk pozostawia także szereg zaleceń mogących uchronić je od niepotrzebnych rozterek i zawsze niebezpiecznych pokus. Nie wypada zatem, aby dziewica słuchała z zainteresowaniem nieskromnych żartów ${ }^{119}$, aby starała się i zabiegała o to, by uchodzić za szczególnie wymowną i nazbyt wesołą ${ }^{120}$. Podpowiada raczej postawę Marii siedzącej u stóp Pana (Łk 10,41-42) niż krzątającej się około jedzenia Marty ${ }^{121}$. Przeznaczonym do dziewictwa nie zaleca otaczania się rzeczami i poddawania się doświadczeniom, których i tak trzeba będzie się wyrzec. Choć, jak utrzymuje, lepiej jest, aby nasyciwszy się, gardziły nimi, niż nie mając,

\footnotetext{
113 Hieronymus, Ep. 22, 5, s. 85*.

114 Hieronymus, Ep. 22, 17, s. $92 *$.

115 Hieronymus, Ep. 22, 8, s. 87*.

116 Hieronymus, Ep. 22, 11, s. 88*.

117 Hieronymus, Ep. 22, 17, s. 92*.

118 Hieronymus, Ep. 22, 27, s. 100*-101*.

119 Hieronymus, Ep. 22, 24, 97*-98*.

120 Hieronymus, Ep. 22, 29, s. 103*.

121 Hieronymus, Ep. 22, 24, s. 98*.
} 
pragnęły mieć122. Swoje pouczenia kieruje do obydwu płci, jak się wyrazi, „nie tylko do słabszego naczynia”. Praktykujących dziewiczy stan mężczyzn przestrzega więc przed towarzystwem kobiety, zwłaszcza młodej, pięknej i rozwiązłej, określając to i strojenie się przy okazji w kosztowną szatę, opływanie w dostatki jako próbę spokojnego snu obok jadowitego węża ${ }^{123}$.

Wielu argumentów dostarcza Hieronimowi w tym względzie prawda o dziewictwie Maryi. Dlatego z niezwykłą gwałtownością atakuje Heliwidiusza podważającego dozgonne dziewictwo Maryi ${ }^{124}$. W celu lepszego zrozumienia zarówno argumentów Hieronima, jak i Helwidiusza warto wspomnieć o dwóch charakterystycznych wówczas nurtach, w kontekście których toczy się spór tych autorów. Otóż jeden z nich, głoszący surową ascezę ${ }^{125}$, wskazywał na wyższość dziewictwa nad małżeństwem. Drugi natomiast, opowiadający się za obroną instytucji małżeństwa, ukazywał Maryję jako małżonkę i matkę w pełnym tego słowa znaczeniu ${ }^{126}$. Innym, dość istotnym $\mathrm{w}$ tym sporze kontekstem były toczące się $\mathrm{w}$ tym czasie polemiki na temat dziewictwa Maryi in partu i post partum ${ }^{127}$. Ich tłem były niewątpliwie poglądy Tertuliana i Orygenesa uznających dziewictwo Maryi ante partum i post partum, ale już nie in partu ${ }^{128}$, które musiały być dobrze znane Hieronimowi. I tak Helwidiusz prowokuje autora Wulgaty do dyskusji na podstawie tekstów biblijnych, co, przy znajomości Pisma Świętego, jest dla Strydończyka dość korzystne ${ }^{129}$. Dokonując zatem bardzo wnikliwej egzegezy, zbija po kolei wszystkie tezy swojego przeciwnika, poczynając od rozstrzygnięcia, zgodnie z którym Maryja została oddana Józefowi pod opiekę (Mt 1,18-20), nie zawierając z nim małżeństwa w pełnym tego słowa znaczeniu ${ }^{130}$. Toteż życie Maryi i Józefa

122 Hieronymus, Ep. 128, 2, s. 179*.

123 Hieronymus, Ep. 128, 3, s. $180 *$.

124 Hieronymus, Adversus Helvidium de Mariae virginitate perpetua, tł. W. Kania, w: Hieronim, Pisma polemiczne: Przeciw Helwidiuszowi; Przeciw Jowinianowi; Przeciw Wigilancjuszowi, red. L. Nieścior, ŹM 67, Tyniec 2013, s. 33-73.

125 A. López Amat, La Vita consacrata. Le varie forme dalle origini ad oggi, Roma 2001, s. 47

126 G. Rocca, L'adversus Helvidium di san Girolamo nel contesto della letteratura ascetico-mariana del secolo IV, Bern 1998, s. 16.

127 G. Rurański, Wstęp, w: Hieronim, Pisma polemiczne: Przeciw Helwidiuszowi, Przeciw Jowinianowi; Przeciw Wigilancjuszowi, red. L. Nieścior, ŹM 67, Tyniec 2013, s. 16-17.

128 Hunter, Marriage, Celibacy and Heresy, s. 181-187.

129 Hieronymus, Adversus Helvidium de Mariae virginitate perpetua 2, ŹM 67 s. 34.

130 Hieronymus, Adversus Helvidium de Mariae virginitate perpetua 3-4, ŹM 67 s. 34-40. 
nie było normalnym pożyciem małżeńskim (Mt 1,24-25), a Jezus był pierworodnym i jedynym Synem Maryi ${ }^{131}$. Hieronim broni dziewictwa Maryi także w piśmie polemicznym Przeciw Jowinianowi, postępując, podobnie jak w sporze z Helwidiuszem, zgodnie z właściwym sobie kluczem chrystologicznym i na podstawie rzetelnej interpretacji Pisma Świętego. Dlatego też uwzględniając wszystkie wypowiedzi Hieronima na temat ideału dziewictwa realizowanego w sposób doskonały przez Maryję, należy wiązać - zarówno ów ideał, jak i jego realizację - z wydarzeniem Jezusa Chrystusa stanowiącego jego najbardziej gruntowne uzasadnienie i zarazem podstawę.

Z kolei wdowieństwo ze względu na Chrystusa doktor Kościoła traktuje jako drugi stopień czystości i doskonałości, czyli - jak pisze - ,pierwsze miejsce po dziewicach" ${ }^{132}$. Dopiero zatem trzecie miejsce zajmuje małżeństwo ${ }^{133}$, a Kościół, choć go nie potępia, to, jak twierdzi Strydończyk, podporządkowuje dziewictwu i wdowieństwu ${ }^{134}$. Pochylając się nad kwestią wdowieństwa, Hieronim rozpatruje je, podobnie jak dziewictwo, w perspektywie chrystologicznej. W liście do Marceli przekonuje, że Odkupicielowi nie mogą podobać się wdowy malujące usta i oczy, troszczące się o ciało dla pożądliwości i w ten sposób wymuszające wdzięk na naturze ${ }^{135}$. Podobnie jak w przypadku dziewictwa Hieronim nie tylko zachęca - przywiązując jednocześnie dużą wagę do zasługującego charakteru tego stanu (większą nagrodę otrzyma młoda wdowa, ponieważ musi zwalczać większe pokusy ${ }^{136}$ ) - lecz zdecydowanie wzywa wdowy do odrzucenia powtórnego małżeństwa. Nie tylko ukazuje niedogodności powtórnego małżeństwa, jak to ma miejsce między innymi w liście do Geruchii pochodzącej z nobilitowanej rodziny rzymskiej, ale sięga przede wszystkim po argumenty teologiczne. Interpretując fragment Pierwszego Listu do Tymoteusza, zalecane przez Pawła powtórne małżeństwo (1Tm 5,14-15) rozumie jako drogę uniknięcia rozpusty, czyli wielkiego zła, a nie związane z jakimś dobrem ${ }^{137}$. W liście do Furii, krewnej Pauli i Pammachiusza poświęconym zachowaniu wdowieństwa, autor Wulgaty jest nie mniej radykalny wobec wdów jak wobec dziewic ${ }^{138}$. Małżeństwo wdowy porównuje do sytuacji symbo-

131 Hieronymus, Adversus Helvidium de Mariae virginitate perpetua 5, ŹM 67, s. 40-41.

132 Hieronymus, Ep. 79, 7, s. 240*-242*.

133 Hieronymus, Ep. 49, 10, s. 206*-207*.

134 Hieronymus, Ep. 49, 11, s. 207*.

135 Hieronymus, Ep. 38, 3, s. 162*.

136 Hieronymus, Ep. 123, 3, s. 124*-125*.

137 Hieronymus, Ep. 123, 3-4, s. 125*.

138 Hieronymus, Ep. 54, 1, s. 37*. 
licznie opisanej przez św. Łukasza w Ewangelii, kiedy to „umarli grzebią swoich umarłych" (Łk 9,60). Wyraża ona brak wystarczającej wiary w Chrystusa, aby za Nim podążyć w kierunku prawdziwego życia. Jak podkreśla Strydończyk, ten, kto wierzy w Chrystusa, powinien postępować tak jak Chrystus ${ }^{139}$ w znaczeniu rezygnacji z małżeństwa ze względu na Chrystusa i po utracie pierwszego stopnia dziewictwa przez trzeci, czyli wdowieństwo, dojść do drugiego, odzyskując w ten sposób wolność i władzę nad swoim ciałem ${ }^{140}$.

Podobnie jak w przypadku pouczeń i przestróg kierowanych do dziewic Hieronim także wdowom zaleca wyrzekanie się wykwintnego życia i skromność ${ }^{141}$. „Płonące pociski diabła należy gasić chłodem postów i czuwania" - napisze ${ }^{142}$, przestrzegając w tym samym liście przed jakimkolwiek posiewem rozkoszy, którego należy unikać jak trucizny ${ }^{143}$. Wzorem wdowy jest dla naszego autora owa uboga kobieta przywołana w Ewangelii według św. Łukasza. Będąc ubogą, jak bardzo była bogata, ponad cały naród izraelski, ponieważ wrzucając wszystko, co posiadała, całe swe bogactwo do skarbony, wykazała się świadectwem wiary podsumowującym oba Testamenty ${ }^{144}$.

\section{Podsumowanie}

Autor Wulgaty, wybitny znawca i tłumacz Pisma Świętego, a także w dzisiejszym tego słowa znaczeniu - systematyk, był przede wszystkim „znawcą” Jezusa Chrystusa, nie w sensie gromadzenia i porządkowania informacji o Bogu zanurzonym w historii człowieka przez wcielenie, ale w dążeniu do doświadczenia i przeżywania Boga w swoim życiu aż po zjednoczenie z Nim w miłości. Najlepszą drogą do tego było dla Hieronima poznanie Biblii, w której Chrystus jest obecny i dzięki której może być naśladowany. I właśnie $z$ potrzeby naśladowania Jezusa, bez czego zjednoczenie z Nim nie jest możliwe, wynika zarówno mniszy sposób życia Strydończyka na pustyni, jak i głoszona przez niego oraz praktykowana bardzo surowa asceza. Jej najważniejszym kryterium, a także najbardziej charakterystycznym rysem jest konsekwentny chrystocentryzm doktora Kościoła z Betlejem. W chrystologicznym

139 Hieronymus, Ep. 54, 2, s. 37*-38*.

140 Hieronymus, Ep. 123, 10, s. $131 *$.

141 Hieronymus, Ep. 123, 4, s. 125*.

142 Hieronymus, Ep. 54, 7, s. 40*.

143 Hieronymus, Ep. 54, 10, s. 42*.

144 Hieronymus, Ep. 54, 17, s. 47*. 
zatem kluczu należy rozumieć i porządkować poglądy Hieronima na temat postu i wyrzeczenia. Zgodnie z tym kluczem, co wynika dość jednoznacznie $\mathrm{z}$ treści jego pism, ascetyczne wątki jego dorobku posiadają, związany z rzeczywistością ogłoszonego przez Jezusa bliskiego Królestwa Bożego, wymiar eschatologiczny. Oceniając z tej perspektywy dobra doczesne, Strydończyk podporządkowuje zdecydowanie rzeczy materialne rzeczywistościom duchowym, co przesądza w zasadzie o znikomości, wprost marności, tych pierwszych. Z kolei te drugie, nawet jeśli zanurzone i realizowane w doczesnej, materialnej rzeczywistości, pozwalają właściwie ustawić hierarchię wartości i tym samym osiągnąć ostateczny cel ludzkiej egzystencji. Nasz autor określa ten cel jako wieczną nagrodę, chcąc w ten sposób niejako wytłumaczyć i uzasadnić konieczny do jej osiągnięcia trud. Pisze wręcz o okrucieństwie w podążaniu na tym świecie za Chrystusem z miłości, przez co rozumie bardzo surowy post i radykalne wyrzeczenie. $Z$ tej też perspektywy nawołuje do dziewictwa ze względu na Chrystusa, przyznając mu pierwszeństwo i oceniając jako bardziej naturalne niż małżeństwo ustępujące również wdowieństwu nazwanemu przez Hieronima „drugim stopniem dziewictwa”.

\section{Christocentric Dimension of Fasting and Mortification in the Writings of St. Jerome of Strydon}

(summary)

Jerome from Strydon is most often presented as a great exegete, expert and translator of the Bible. Sometimes, it is also reminded about his significant achievements in theological disputes. Meanwhile, Jerome himself in his numerous writings and activities presents himself to contemporary and living later people as an ascetic very demanding from himself and from others. Practicing the monks' lifestyle in the desert and devoting himself to scientific work, he sought to get to know Jesus Christ as best as possible, to imitate Him as much as possible and to unite with Him through his personal experiences. Therefore, he considers these two paths, that is, the study of the Bible and penance and renunciation, as the best for this; besides - as he often emphasizes - paths mutually conditioning and supportive. In his ascetic theology, there are topics related to the deserving nature of Christian mortification. Jerome sees the basis of this in his very clear eschatological inclination. It is the basic criterion in determining by him the vanity of all that is temporal because of what is eternal and spiritual. Christocentrically understood by him, the idea of the Kingdom of God, already present in temporality, becomes the most important argument in requiring Christians to live a proper full realization of this reality in heaven. In his opinion, this is best served by renunciation reaching up to the sacrifice of one's life. And this is best explained by the Savior's way, calling for a life with Him in the glory of heaven through mortification with Him on earth.

Keywords: Jerome; Christocentrism; renunciation; penance; sacrifice; fasting; virginity; widowhood 


\title{
Chrystocentryczny wymiar postu i umartwienia w pismach św. Hieronima ze Strydonu
}

\author{
(streszczenie)
}

Hieronim ze Strydonu przedstawiany jest najczęściej jako wielki egzegeta i znawca oraz thumacz Pisma Świętego. Niekiedy przypomina się również o jego znaczących dokonaniach w sporach teologicznych. Tymczasem sam Hieronim w swoich licznych pismach i działaniach przedstawia się sobie współczesnym i potomnym jako bardzo wymagający od siebie i od drugich asceta. Praktykując mniszy styl życia na pustyni i poświęcając się pracy naukowej, dążył do jak najlepszego poznania Jezusa Chrystusa, aby Go jak najlepiej naśladować i przez swoje osobiste doświadczenia z Nim się jednoczyć. Dlatego też te dwie drogi, czyli studium Biblii oraz pokutę i wyrzeczenie, uznaje za najlepsze w tym celu. Poza tym - jak często podkreśla - wzajemnie się one warunkują i wspomagają. W jego teologii ascetycznej do głosu dochodzą tematy związane z zasługującym charakterem chrześcijańskiego umartwienia. Podstawę tego Strydończyk dostrzega w swoim bardzo wyraźnym wychyleniu eschatologicznym. Stanowi ono podstawowe kryterium w określaniu przez niego marnością wszystkiego, co doczesne, ze względu na to, co wieczne i duchowe. Chrystocentrycznie rozumiana przez niego idea Królestwa Bożego, obecnego już w doczesności, staje się najważniejszym argumentem w wymaganiu od chrześcijan życia właściwego pełnej realizacji tej rzeczywistości w niebie. Najlepiej temu służy - w jego przekonaniu - wyrzeczenie aż po ofiarę z własnego życia. Najlepiej zaś to tłumaczy taka właśnie droga Zbawiciela wzywającego do wspólnego z Nim życia w chwale nieba przez wspólne z Nim umartwienie na ziemi.

Słowa kluczowe: Hieronim; chrystocentryzm; wyrzeczenie; pokuta; ofiara; post; dziewictwo; wdowieństwo

\section{Bibliografia}

\section{Źródła}

Hieronymus, Commentariii in IV epistulas Paulinas. Ad Titum, w: Ambrozjaster, Hieronim, Pelagiusz, Komentarze do Listu św. Pawła do Tytusa, tł. A. Baron, Kraków 2003, s. 125-190.

Hieronymus, Commentarii in Evangelium Matthaei, tł. J. Korczak, Kraków 2008.

Hieronymus, Epistulae, t. 1-5, tł. J. Czuj, Kraków 2010.

Hieronymus, Commentarius in Ecclesiasten, tł. K. Bardski, Kraków 1995.

Hieronymus, Adversus Helvidium de Mariae virginitate perpetua, w: Hieronim, Pisma polemiczne: Przeciw Helwidiuszowi; Przeciw Jowinianowi; Przeciw Wigilancjuszowi, thum. W. Kania - L. Nieścior - G. Rurański, Tyniec 2013, s. 33-73.

Hieronymus, Adversus Iovinianum, w: Hieronim, Pisma polemiczne: Przeciw Helwidiuszowi; Przeciw Jowinianowi; Przeciw Wigilancjuszowi, tł. W. Kania - L. Nieścior G. Rurański, Tyniec 2013, s. 115-384.

Hieronymus, Commentariorum in Ionam prophetam liber unus, tł. L. Gładyszewski, Kraków 1998. 


\section{Opracowania}

Bartnik C.S., Fenomen Europy, Radom 2001.

Bourgeois H. - Sesboüé B. - Tihon P., Znaki zbawienia, t. 3, tł. P. Rak, w: Historia dogmatów, red. B. Sesboüé, Kraków 2001.

Chauffin Y., Święty Hieronim, tł. B. Durbajło, Warszawa 1977.

Czuj J., Św. Hieronim. Żywot-dzieła. Charakterystyka, Warszawa 1954.

Degórski B., Wstęp, w: Hieronim, Żywoty mnichów Pawła, Hilariona, Malchusa, tł. B. Degórski, Kraków 1995, s. 11-57.

Goodman M., Rzym i Jerozolima. Zderzenie antycznych cywilizacji, tł. O. Zienkiewicz, Warszawa 2007.

Hunter D., Marriage, Celibacy and Heresy in Ancient Christianity: The Jovinianist Controversy, Oxford 2007.

Jelonek T., Hieronim, Kraków 2003.

Labriolle P., La réaction païenne. Étude sur la polémique antichrétienne du ler au VI siècle, Paris 1984.

Lieu J.M., Christian Identity in the Jewish and Graeco-Roman World, Oxford 2004.

López Amat A., La Vita consacrata. Le varie forme dalle origini ad oggi, Roma 2001.

Mara M.G., Paulo di Tarso e il suo Epistolario. Ricerche storico-esegetiche, L'Aquila 1983.

Nieścior L., Wstęp, w: Hieronim, Pisma polemiczne. Przeciw Helwidiuszowi. Przeciw Jowinianowi. Przeciw Wigilancjuszowi, red. L. Nieścior, ŹM 67, Tyniec 2013, s. 75-113.

Origene - Girolamo, 74 omelie sul Libro dei salmi, ed. G. Coppa, Milano 1992.

Paczkowski M.C., Chrystologia Hieronima na tle teologii palestyńskiej przełomu IV $i$ V wieku, VoxP 48 (2005) s. 159-186.

Rives J.B., The Decree of Decius and the Religion of Empire, „Journal of Roman Studies” 89 (1999) s. 135-154.

Rocca G., L'adversus Helvidium di san Girolamo nel contesto della letteratura ascetico-mariana del secolo IV, Bern 1998.

Rurański G., Wstęp, w: Hieronim, Pisma polemiczne: Przeciw Helwidiuszowi; Przeciw Jowinianowi; Przeciw Wigilancjuszowi, red. L. Nieścior, ŹM 67, Tyniec 2013, Tyniec 2013, s. 13-31.

Stark R., The Rise of Christianity. A Sociologist Reconsiders History, Princeton 1996. 